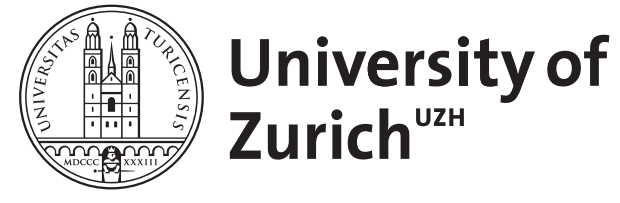
Archive

University of Zurich

University Library

Strickhofstrasse 39

CH-8057 Zurich

www.zora.uzh.ch

Year: 2004

\title{
Review: Samuel Beckett Compagnie
}

Hunkeler, T

DOI: https://doi.org/10.1093/fs/58.3.442

Posted at the Zurich Open Repository and Archive, University of Zurich

ZORA URL: https://doi.org/10.5167/uzh-154726

Journal Article

Published Version

Originally published at:

Hunkeler, T (2004). Review: Samuel Beckett Compagnie. French Studies, 58(3):442-443.

DOI: https://doi.org/10.1093/fs/58.3.442 
fragmentation and dispersal; the centripetal perpetuation of a binary whereby the non-metropolitan is exoticized; an assimilationist approach whereby it is normalized; or a more fundamental response (epitomized by Lawrence D. Kritzman's contribution) that involves a more general restructuring and an integrative understanding of the interaction between 'French' and 'Francophone' dependent on 'hermeneutic strategies that are both comparative and dialogic in nature'. Such a range of responses reflects the contributors' variety of positions, and the heterogeneity of the volume is one of its strengths. Sandy Petrey firmly defends a hexagonal focus against what he sees as potentially 'Francophobic inquiry', whereas Mireille Rosello performs a provocative reversal, suggesting that 'Hexagonal literature is a branch of Francophone Studies'. Other contributions outline an interdependence that is more difficult to unravel, with Jean Jonassaint explaining the ways in which French and francophone in a Caribbean context are 'to a certain extent, part of one another', and Michael Dash exploring the subtle imbrications of Caribbean and metropolitan travel writing around the Second World War. Naomi Schor, to whose memory the volume is dedicated, sums up this need for new interpretative models: 'canon-enlargement [...] is bound up with a call for a thorough transformation of the ways one reads'. What underpins all the essays, however, is an awareness that non-metropolitan francophone literatures and cultures can no longer be subject to what Réda Bensmaïa describes as a fundamental 'scotomization process' or can no longer be dismissed as a 'passing fad'. Despite acknowledged problems concerning nomenclature (Karen L. Gould presents the epithet 'Francophone' as a 'homogenizing designation'; Rosello presents francophone studies as a 'performative statement'), the persistence in scholarly enquiry and theoretical reflection of the amorphous referent or subject of such designations is unquestioned. The scope of the volume is international, although its emphasis is primarily on the meeting of postcolonial criticism and French/francophone studies in the North American academy. Different narratives might emerge, were the British and Irish experience of similar issues addressed, as the opinion pieces contributed to the first three issues of the newly launched journal Francophone Postcolonial Studies make clear. This special issue of Yale French Studies is essential reading, not only for scholars concerned with current trends in (francophone) postcolonial criticism, but also for those with a more general interest in the current and future manifestations of a globalized French studies.

Charles Forsdick

UNIVERSITY OF LIVERPOOL

Samuel Beckett \& Compagnie. By SJeF Houppermans. (Faux Titre, 235). Amsterdam - New York, Rodopi, 2003. I 53 pp. Pb \$33.00; $€_{30.00 .}$

Ce volume, dû à l'un des éditeurs en chef de la revue Samuel Beckett Today/Aujourd'bui, regroupe une série de douze études (pour la plupart déjà parues ailleurs) ayant pour sujet ce que le critique considère comme l'un des traits les plus marquants de l'œuvre beckettienne, à savoir la quête de quelqu'un à qui parler. Cette perspective amène Houppermans à évoquer la relation que l'œuvre beckettienne entretient avec les 'grandes voix du passé' comme Dante, Joyce et surtout Proust, mais aussi avec les 'compagnons de route' comme Claude Simon ou Robert Pinget. A partir 
notamment de ce qu'on appelle la seconde trilogie de l'auteur, c'est-à-dire Compagnie, Mal vu mal dit et Cap au pire, Houppermans cherche ainsi à dégager deux tendances concomitantes de l'écriture beckettienne : la compulsion de répétition, qui vise à un retour vers le non-être, mais aussi le refus de toute résignation, qui produit à chaque fois un nouveau (faux) départ. En se basant principalement, dans ses interprétations, sur les acquis de la psychanalyse (Lacan, Abraham/Torok, Anzieu), Houppermans tente de montrer que l'œuvre de Beckett se caractérise par 'l'enchevêtrement inextricable du double scénario "bâtard/enfant trouvé", cherchant ainsi à réunir les deux destins du roman familial distingués par Marthe Robert à la suite de Freud. On notera la belle étude intitulée 'A cheval', où le critique relit l'échec du modèle œdipien dans la nouvelle L'Expulsé à la lumière du cheval dans le cas du petit Hans étudié par Freud, ou encore son commentaire éclairant sur la nature désappropriante du deuil dans Mal vu mal dit, ce texte mélancolique qui est à comprendre non seulement comme un 'acte d'incorporation', mais aussi comme un 'écrit d'excorporation', oscillant constamment entre la boulimie et l'anorexie. Le livre se clôt sur une série de remarques visant à rapprocher l'écriture beckettienne de la pensée deleuzienne, qui sous-tend en filigrane l'argumentation de Houppermans. A la philosophie 'du puits', qui tend à travers un processus de disjonctions exclusives à l'établissement d'une vérité cachée, le critique oppose une philosophie du 'puis', opérant à l'instar de l'art beckettien par disjonctions inclusives. L'art de l'épuisement que Deleuze voit à l'œuvre chez Beckett servirait dans ce sens de modèle pour dépasser les entités figées chères à la critique traditionnelle ; il permettrait ainsi de glisser de la négation des grands projets modernistes à une non-intentionnalité postmoderne, réussissant une fusion artistique que Houppermans propose d'appeler 'transmoderne'.

Thomas Hunkeler

UNIVERSITÄT ZÜRICH

Popular Music in Contemporary France: Authenticity, Politics, Debate. By David L. Looseley. Oxford, Berg, 2003. xii +254 pp. Hb f,50.00. Pb fi 5 .००.

David L. Looseley's excellent study has a twofold purpose: to trace the history and naturalization of Anglo-American styles of pop music in France and to analyse 'the discourses and debates it has generated, the different ways in which it has been written about and argued over in the public sphere since $1958^{\prime}$ (p. 2). The book is divided into two parts: the first gives a brief history of French pop (which is ultimately inseparable from chanson), whilst the second examines the responses of the state, focusing on how 'both pop and policy have been conceptualised and debated' (p. 5). Part I examines the impact in France of Anglo-American music, paying particular attention to the notion of métissage. Within this part of the book, Chapter 5 engages with social scientists who, from Morin, Bourdieu, Certeau and others, to Mayol, Hennion and Maffesoli, have proffered a range of views which became increasingly interested in reception rather than production. Part 2 examines the role of successive culture ministers from Malraux to Trautmann, demonstrating, in particular, the impact of Jack Lang in encouraging, and to some degree financing, new forms of music. Of particular interest is Looseley's analysis of the state's attitude towards techno in Chapter ı。. His Conclusion leads him to assert that 